\title{
Prostasomes: a role in prostatic disease?
}

ALISTAIR B. STEWART, WILLIAM ANDERSON*, GEORGE DELVES*, BASHIR A. LWALEED, BRIAN BIRCH and ALAN COOPER + Department of Urology, Southampton University Hospitals NHS Trust, *St Mary's Hospital, Portsmouth, and PPortsmouth University, Portsmouth, UK

Accepted for publication 20 July 2004

\section{KEYWORDS}

prostasomes, prostate disease, structure, function

\section{INTRODUCTION}

Prostasomes are membrane-bound secretory vesicles, in the nanometre diameter range, secreted by the prostatic ductal epithelium [1] into the lumen, where they form part of the ejaculate. Although known to have specific biological properties, their physiological role and overall significance remain far more debatable. There has been comparatively little written about these structures since their detection two decades ago, and this may help explain the relative lack of awareness of prostasomes within the urological community.

\section{ORIGIN AND PHYSICAL PROPERTIES}

\section{PRODUCTION AND SECRETION OF PROSTASOMES}

Prostasomes are produced in the apical part of the prostatic ductal epithelial cell where the Golgi apparatus is abundant. Many prostasomes appear together within larger storage vesicles before secretion into the prostatic ductal lumen. There are thought to be two main modes of prostasome secretion. In exocytosis, larger storage vesicles fuse with the cell membrane to discharge their contents, followed by recycling of the vesicular membrane. Secretion in membranebound form, or diacytosis, involves the whole storage vesicle together with its contained prostasomes being translocated through the membrane (as happens with hepatic phospholipids). They are thought to occur with about equal frequency [1]. This is supported by the morphological finding of both free prostasomes and membrane-bound groups of prostasomes within the ductal lumen.

\section{PROSTASOMAL STRUCTURE}

Prostasomes are found in high concentrations in seminal plasma. Under electron microscopy there appear to be two distinct morphological types: smaller, 'dark' prostasomes with tightly packed electron-dense contents, and larger 'light' less dense structures (Fig. 1). Their diameter is 40-500 $\mathrm{nm}$ [1]. They have a lipid bilayer membrane which may be arranged in a multilamellar fashion, and has a characteristically high concentration of cholesterol. Consequently, prostasomes have a membrane which is less permeable to small water-soluble molecules. Analogous structures are also shed by prostate cell lines into culture media [2].

\section{PREPARATION OF PROSTASOMES}

Prostasomes can be prepared from both in-vitro and in-vivo sources, using semen, prostatic tissue (benign, primary and secondary malignancy) or prostate cancer cell lines. Although the finer details of extraction will depend upon the source, the protocols used to isolate prostasomes contain the following elements:

- Removal of cells from semen by low-speed centrifugation.

- Ultracentrifugation of seminal plasma, e.g. $100000 \mathrm{~g}$ for $2 \mathrm{~h}$.

- Re-suspension of the prostasome pellet, typically in isotonic Tris- $\mathrm{HCl}$ buffer.

- Gel chromatography, e.g. using a 'superdex' column, to purify the re-suspended prostasome containing fractions.

\section{BIOCHEMISTRY}

LIPIDS

One of the main lipid components of prostasomes is sphingomyelin [1], a phospholipid, which contains 1phosphocholine combined with a ceramide (an $\mathrm{N}$-acyl long-chain base) such as sphingosine. Sphingomyelin is one of the main constituents of the myelin sheath of neurones. More than half of the phospholipid component of the prostasomal membrane is either palmitic $\left(\mathrm{COOH}\left(\mathrm{CH}_{2}\right)_{14} \mathrm{CH}_{3}\right)$ or stearic acid $\left(\mathrm{COOH}\left(\mathrm{CH}_{2}\right)_{16} \mathrm{CH}_{3}\right)$. The ratio of cholesterol to phospholipid is about $2: 1$, compared to $1: 1$ in a typical mammalian cell membrane [1].

\section{PROTEINS}

A recent proteomic analysis using an HPLCmass spectrometry approach trawled 139 associated proteins in prostasomes isolated from pooled semen [3]. The authors hypothesise that prostatic diseases may present unique phenotypes at the level of their respective prostasomal proteomes. Some previously identified proteins (e.g. CD142, see below) do not appear in this analysis; $9 \%$ appeared to be novel. The functions of the 'known' molecules are diverse and include structural membrane proteins, enzymes, chaperone proteins and signal transduction molecules. Some have particular relevance in the genitourinary tract and inform speculation on the biological effects of the prostasome; Table 1 [4-14] lists some of the more interesting candidates, but the exact function of many prostasomal proteins remains unclear.

Tissue factor (TF), alias thromboplastin or CD 142 , is a transmembrane glycoprotein with a molecular weight of $\approx 29 \mathrm{kDa}$. It is a receptor and essential cofactor for clotting factors VII and VIla, and acts as the main physiological initiator of the coagulation cascade. TF is present in human semen, predominantly in the prostasomal fraction, and has been located on the prostasomal surface using immuno-electron microscopy (Table 1 [11]).

Neuroendocrine components, e.g. neuropeptide $Y$, chromogranin $A$ and $B$, and vasoactive intestinal peptide, have also been detected in prostasomes by radioimmunoassay. Skibinsky et al. [10] identified the secretory granule protein 


\begin{tabular}{|c|c|c|}
\hline Protein & Putative function & Reference \\
\hline CD 13, aminopeptidase & Zinc-dependent proteolytic enzyme. Liquefaction of semen. & [4] \\
\hline CD 26, dipeptidyl peptidase IV & $\begin{array}{l}\text { Peptide metabolism, T-lymphocyte activation and the regulation of DNA synthesis, cell } \\
\text { proliferation and the production of cytokines. HIV binding. }\end{array}$ & [5] \\
\hline $\begin{array}{l}\text { CD 10, enkephalinase } \\
\text { (neutral endopeptidase) }\end{array}$ & $\begin{array}{l}\text { Membrane-anchored ectoenzyme (peptidase). Regulation of growth stimulatory capacity } \\
\text { Lost in hormone-insensitive invasive prostate cancer cell lines }\end{array}$ & [6] \\
\hline $\begin{array}{l}\text { CD 143, angiotensin converting } \\
\text { enzyme }\end{array}$ & Angiotensin 2 and bradykinin metabolism & [7] \\
\hline CD $46,55,59$ & $\begin{array}{l}\text { Complement inhibitors. Sperm motility. Protection of sperm against complement attack } \\
\text { in the female genital tract }\end{array}$ & {$[8,9]$} \\
\hline CD 69, granulophysin & $\begin{array}{l}\text { Facilitate molecular interactions. Increasing the formation and stability of functional } \\
\text { signalling complexes }\end{array}$ & [10] \\
\hline CD 142, TF & Rapid activation of clotting, preventing bleeding and transfer of infection & [11] \\
\hline ATPase & $\begin{array}{l}\text { Vectorial calcium transport into prostasomes. Prostasomes are rich in } \mathrm{Ca}^{2+} \text {, and } \\
\text { participate in the maintenance of } \mathrm{Ca}^{2+} \text { homeostasis which is necessary for sperm motility }\end{array}$ & [12] \\
\hline $\begin{array}{l}\mathrm{Ca} / \mathrm{Mg} \text { dependent heat-shock } \\
\text { proteins, including Hsp70 and } 90\end{array}$ & $\begin{array}{l}\text { Chaperon proteins. Promotion of protein folding, assembly, translocation and secretion } \\
\text { of newly formed polypeptides. Hsp } 90 \text { targets signal transduction proteins, e.g. steroid } \\
\text { hormone receptors and signalling kinases }\end{array}$ & [13] \\
\hline PSA & Tumour marker for prostate cancer. Semen liquefaction. & [14] \\
\hline
\end{tabular}

granulophysin, which is structurally similar to the neuroprotein synaptophysin (Table 1).

\section{PROSTASOMAL FUNCTION}

Function depends on the source of prostasomes; for instance, if sperm motility is considered, prostasomes isolated from PC3 cell lines have similar properties to those isolated from seminal plasma [15], whereas amino-peptidase activity differs [2]. The identification of prostasome-associated proteins sheds light on the possible function of prostasomes (Table 1 [4-14]). It is postulated that they have a role in sperm motility, semen calcium homeostasis, semen liquefaction, complement inhibition, immunosuppression, prevention of haematogenous infection, clotting activation, and even a role in HIV transmission. They are also reputed to have antioxidant properties.

\section{SPERM-PROSTASOME INTERACTIONS}

The evidence suggests that by sperm prostasome-interaction, advantageous effects of prostasomal membrane proteins are conferred to the sperm cell, resulting in an improved microenvironment and an increased chance of the sperm cell achieving successful fertilization. Sperm fusion with prostasomes has been an area of some interest. Ronquist et al. [16] reported that both the spermatozoa and prostasomes have a net negative surface charge, with the prostasome being less negative. Fusion occurs despite the expected repulsion, raising further questions about sperm-prostasomal interaction. It has been shown that fusion between sperm and prostasomes is $\mathrm{Ca}^{2+}$-dependent and involves increasing sperm intracytoplasmic $\mathrm{Ca}^{2+}$ concentrations (Table 1 [12]).

Fabiani et al. [17] showed an increase in sperm motility in semen samples treated with prostasomal preparations, with a response rate of up to $70 \%$. Motility may even occur in sperm that are initially deemed to be immotile. The increased sperm motility attributable to prostasomes is $\mathrm{pH}$-dependent. This may be physiologically significant, as sperm encounter an acidic environment on ascending the female genital tract. Sperm motility was shown by Arienti et al. [18] to be decreased in an acidic environment, but this was improved by adding prostasomes. Thus, it is possible that prostasomes offer some buffering protection for the sperm against the relatively harsh vaginal/uterine environment. However, these discoveries do not appear to have led to widespread clinical application within infertility management, perhaps raising doubts about the overall significance of the results.

Prostasomes are thought to promote sperm motility by modulating calcium ion concentrations. Prostasomes are rich in calcium ions and the prostasome-associated $\mathrm{Ca} / \mathrm{Mg}$ ATPase system may control their transport across the prostasome membrane. Annexins and calmodulin are other proteins involved with $\mathrm{Ca}^{2+}$ regulation that are present in prostasomes.

Although the mechanisms involved in the acrosome reaction are not completely understood, Arienti et al. [19] suggested that the sperm membrane appears to stabilise on fusing with prostasomes because of enrichment with cholesterol, sphingomyelin, and saturated glycerophospholipid. It is argued that this may 'prevent the untimely occurrence of the acrosome reaction' [19]. The significance of other molecules, including arachidonic acid 15-lipoxygenase, has also been noted; it has been implicated in the acrosome reaction of bull semen and was found by Oliw et al. [20] to be present in purified human prostasomes.

\section{SEMEN COAGULATION AND LIQUEFACTION}

Immediately after ejaculation normal human semen coagulates. The coagulum is largely composed of the of sialoglycoprotein-metal complexes (semenogelins), glycerylphosphorylcholine and fibronectin, the whole being known as high molecular weight seminal vesical 
FIG. 1. Transmission electron microscopy of (a) dark prostasomes, diameter $\approx 150 \mathrm{~nm}$, and (b) light prostasomes, the diameter of large light prostasomes being $\approx 300 \mathrm{~nm}$.
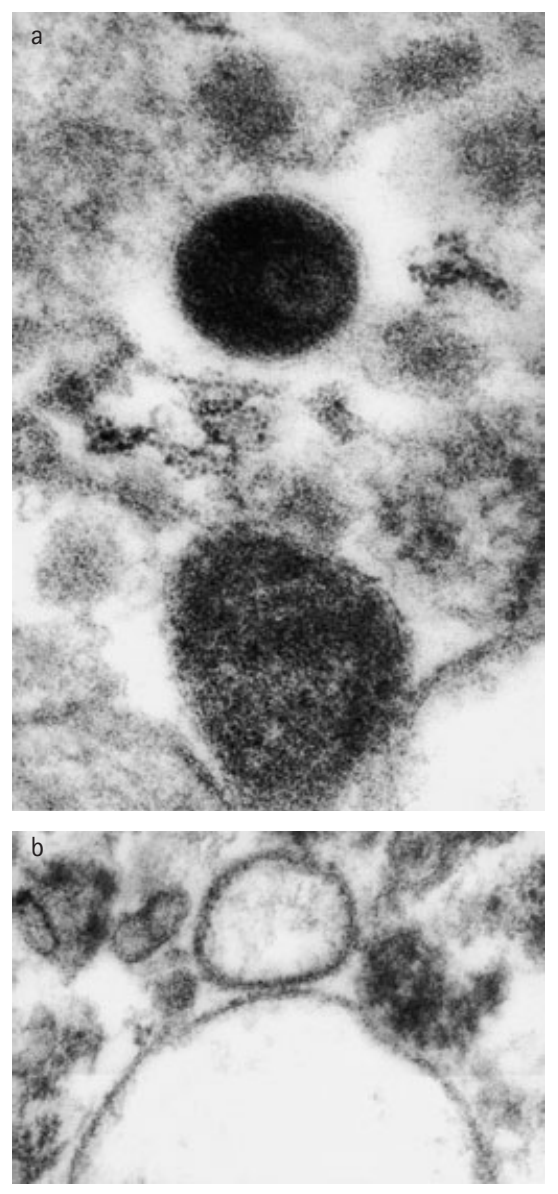

proteins (HMW-SVP) [21]. Within $\approx 20 \mathrm{~min}$, spontaneous liquefaction occurs by the action of PSA (a serine protease present in seminal plasma, both free and prostasomeassociated [3]) and possibly the involvement of prostasome aminopeptidase, a zincdependent proteolytic enzyme (Table 1 [4]).

\section{THE HAEMOSTATIC SYSTEM IN SEMEN}

There is evidence that most of the components of the blood coagulation and fibrinolytic system are present in semen. There are points of contact between these and the HMW-SVP system, notably PSA, which binds to protein-C inhibitor. Moreover, digestion of semenogelin with PSA produces fragments which cross-link into complexes with clotting Factor XIIla [22]. This circumstance is a reminder not to assign exclusive categories to groups of molecules; semen contain many interrelating proteases. Because of its prostasomal (and perhaps some soluble) TF content, semen has potent blood-clotting activity. The ability to coagulate blood rapidly from abrasions during intercourse is postulated to prevent sperm and seminal components, including infectious agents such as HIV, from entering the blood stream, generating antibodies, or promoting infectious disease.

\section{EFFECTS ON THE LYMPHORETICULAR SYSTEM AND IMMUNITY}

Human semen has potent

immunosuppressive activity [23], thought to help protect sperm from immunological attack within the female reproductive tract. Local immunosuppression may also help to protect the female genital tract from becoming sensitized to the allo-antigenic proteins present in seminal plasma and on sperm.

Prostasomes inhibit lymphocyte proliferation and protect sperm cells from macrophage phagocytosis [24]. CD46,55 and 59 on prostasomes have been shown to regulate complement pathways and opsonization (Table $1[8,9]$ ). CD46 causes proteolytic inactivation of factors $\mathrm{C} 3 \mathrm{~b}$ and $\mathrm{C} 4 \mathrm{~b}$ of the complement cascade. CD55, the decay accelerating factor, and CD59, an inhibitor of the membrane attack complex, both protect from complement-mediated lysis and phagocytosis.

\section{HIV INFECTION}

Prostasomes may facilitate HIV binding and survival in human semen. CD26 (dipeptidylpeptidase), a prostasomal membrane protein, binds HIV (Table 1 [5]). Second, the complement inhibitors CD46, 55 and 59 that protect sperm may also protect the HIV virus. Indeed CD55 and CD59 might become transferred from the prostasome to the HIV membrane (Table 1 [8]).

\section{ANTIOXIDANT PROPERTIES}

Reactive oxygen species or free radicals are pivotal in inflammation and carcinogenesis. They are harmful to sperm and a major cause of idiopathic male infertility.
Polymorphonuclear leukocytes in semen are thought to be a major local source of reactive oxygen species. The addition of prostasomes to polymorphonuclear leukocytes caused a reduction of these free radicals [25]. The authors attributed this decrease not to freeradical scavenging, but the incorporation of 16-doxyl-stearate into the cell membranes, increasing rigidity.

\section{THE ROLE OF PROSTASOMES IN UROLOGICAL DISEASE, AND CURRENT RESEARCH}

Prostate cancer cells generate prostasomelike granules [2]; antibodies to prostasomes have been detected in the serum of patients with prostate cancer. A pilot study by Nilsson et al. [26], using ELISA technology, showed markedly higher serum levels of antibodies to prostasomes in patients with prostate cancer than in control subjects. This work used a prostasome-like preparation made from prostate tissue. Our ongoing and as yet unpublished experimental results, using seminal prostasomes from vasectomized men as antigen, give a much lower rate of positivity in sera from patients with prostate cancer. Further work is required to establish the role of antibodies to prostasomes as prognostic indicators and determinants in tumour progression. The antigenic target(s) need identifying. Nilsson's group chose a monoclonal antibody for their studies, and thus detected antibodies to one epitope only on these complex structures. It is not apparent how many specificities emerged from their fusions. The metastatic status of the patients in that study was not recorded. Local invasion or metastasis should facilitate prostasomes escaping into the vascular and lymphatic systems. Leaked prostasomes may also impinge on the course of whatever pathological process caused their presence there, for good or ill. The ease with which prostasomal membrane elements apparently fuse with cells and pathogens gives much scope for them to influence events.

Relatively little has been published on the potential role of prostasomes in urological disease. Recent work by Carlsson et al. [27] suggests that prostasomes have a growth inhibitory effect on prostatic cancer cell lines in culture, with the effect being most marked with DU145 cells. The possibility of in-vivo growth-inhibition should therefore be considered. 
TF has been implicated in breast cancer as a marker for the switch to an angiogenic phenotype. The role, if any, of prostasomebound TF in prostate cancer angiogenesis has yet to be determined. Malignancy has long been associated with hypercoagulability, presumably involving TF. Urinary exosomes, derived from kidney tubular epithelium, also carry TF [28], and their potential as diagnostic or prognostic markers of malignancy is well described [29]. Abdulkadir et al. [30] implicated urinary TF expression as being correlated with PSA levels in prostate carcinoma, and the procoagulant activity of prostatic tissue in an experimental model of prostate cancer in rats was highest in metastatic disease [31].

\section{CONCLUSIONS}

Prostasomes are relatively neglected entities, certainly in urology. The search term 'prostasomes' reveals only 81 papers in Pubmed, averaging four per year since their discovery. There is an overview of the field from other than a urological perspective [32]. Prostasomes are best known in domains of human and veterinary fertility, but given their readiness to fuse with cells, their content of potentially influential molecules, and antioxidant properties, it can be argued that prostasomes are more than just vehicles for the disposal of unwanted cellular material. This may or may not be the case for the exosomes produced by prostate cell lines in vitro and caution should be exercised in assuming homology. There are also seminosomes, liberated in the testis and presumably contaminating prostasome preparations (except in vasectomized individuals). Indeed, experimental comparisons between prostatic exosomes and those released by other epithelia would help to differentiate the specific prostasomal properties from more general attributes.

There is circumstantial evidence that prostasomes might have some influence on proliferative events in the prostate. Antibodies that react with prostasomes, whatever the original immunogen, are intriguing both for their very existence and the opportunities for the pathophysiological effect they suggest. It is timely for academic urologists to address the pathophysiology of prostasomes, in particular more prostate-specific issues, e.g. prostatic carcinoma, prostatitis and $\mathrm{BPH}$.

\section{CONFLICT OF INTEREST}

None declared.

\section{REFERENCES}

1 Ronquist G, Brody I. The prostasome. its secretion and function in man. Biochim Biophys Acta 1985; 822: 203-18

2 Nilsson BO, Lennartsson L, Carlsson L, Nilsson S, Ronquist G. Expression of prostasome-like granules by the prostate cancer cell lines PC3, DU145 and LnCaP grown in monolayer. Ups J Med Sci 1999; 104: 199-206

3 Utleg AG, Yi EC, Xie T et al. Proteomic analysis of human prostasomes. Prostate 2003; 56: 150-61

4 Lilja $\mathrm{H}$, Laurel CB. Liquefaction of coagulated human semen. Scand J Clin Laboratory Invest 1984; 44: 447-52

5 Valenzuela A, Blanco J, Callebaut C etal. Adenosine deaminase binding to human CD26 is inhibited by HIV-1 envelope glycoprotein gp120and viral particles. J Immunol 1997; 158: 3721-9

6 Papandreou CN, Usmani B, Geng Y et al. Neutral endopeptidase 24.11 loss in metastatic human prostate cancer contributes to androgen-independent progression. Nat Med 1998; 4: 50-7

7 Erdos EG, Schulz WW, Gafford JT, Defendini R. Neutral metalloendopeptidase in human genital tract. Comparison to angiotensin I converting enzyme. Lab Invest 1985; 52 : 437-47

8 Rooney IA, Atkinson JP, Krul ES et al. Physiologic relevance of the membrane attack complex inhibitory protein CD59 in human seminal plasma: CD59 is present on extracellular organelles (prostasomes), binds cell membranes, and inhibits complement-mediated lysis. J Exp Med 1993; 177: 1409-20

9 Kitamura M, Namiki M, Matsumiya K et al. Membrane cofactor protein (CD46) in seminal plasma is a prostasome-bound form with complement regulatory activity and measles virus neutralising activity. Immunology 1995; 84: 626-32

10 Skibinski G, Kelly RW, James K. Expression of a common secretory granule specific protein as a marker for the extracellular organelles (prostasomes) in human semen. Fertil Steril 1994; 61 : 755-9

11 Fernandez JA, Heeb MJ, Radtke KP,
Griffin JH. Potent blood coagulant activity of human semen due to prostasome-bound tissue factor. Biol Reprod 1997; 56: 757-63

12 Arienti G, Carlini E, Saccardi C, Palmerini CA. Nitric oxide and fusion with prostasomes increase cytosolic calcium in progesterone-stimulated sperm. Arch Biochem Biophys 2002; 402: 255-8

13 Young JC, Moarefi I, Hartl FU. Hsp 90: a specialised but essential protein folding tool. J Cell Biol 2001; 154: 267-73

14 Crawford ED, DeAntoni EP. PSA as a screening test for prostate cancer. Urol Clin North Am 1993; 20: 637-46

15 Wang J, Lundquist $\mathrm{M}$, Carlsson L, Nilsson 0, Lundquist O, Ronquist G. Prostasome-like granules from the PC-3 prostate cancer cell line increase the motility of washed human spermatozoa and adhere to the sperm. EurJ Obstet Gynecol Reprod Biol 2001; 96 : 88-97

16 Ronquist G, Nilsson BO, Hjerten S. Interaction between prostasomes and spermatozoa from human semen. Arch Androl 1990; 24: 147-57

17 Fabiani R, Johansson L, Lundkvist 0, Ronquist G. Enhanced recruitment of motile spermatozoa by prostasome inclusion in swim up medium. Hum Reprod 1994; 9: 1485-9

18 Arienti G, Carlini E, Nicolucci A, Cosmi EV, Santi F, Palmerini CA. The motility of human spermatozoa as influenced by prostasomes at various pH levels. Biol Cell 1999; 91: 51-4

19 Arienti G, Carlini E, Saccardi C, Palmerini CA. Fatty acid pattern of human prostasome lipid. Arch Biochem Biophys 1998; 358: 391-5

20 Oliw EH, Fabiani R, Johansson L, Ronquist G. Arachidonic acid 15lipoxygenase and traces of $E$ prostaglandins in purified human prostasomes. J Reprod Fertil 1993; 99: 195-9

21 Gonzales GF. Function of seminal vesicles and their role in male fertility. Asian J Androl 2001; 3: 251-8

22 Lwaleed BA, Greenfield R, Stewart AB, Cooper AJ, Birch B. Seminal clotting and fibrinolytic balance: Possible role in fertility. Thrombosis and Haemostasis 2004; 92: 752-66

23 Stites DP, Erickson RP. Suppressive effect of seminal plasma on lymphocyte activation. Nature 1975; 235: 727-9 
24 Jiang H, Pillai S. Complement regulatory proteins on the sperm surface. Relevance to sperm motility. Am J Repro Immun 1998; 39: 243-8

25 Saez F, Motta C, Boucher D, Grizard G. Antioxidant capacity of prostasomes in human semen. Mol Hum Reprod 1998; 4: 667-72

26 Nilsson BO, Carlsson L, Larsson A, Ronquist G. Autoantibodies to prostasomes as new markers for prostate cancer. Ups J Med Sci 2001; 106: 43-9

27 Carlsson L, Lennartsson L, Nilsson BO, Nilsson S, Ronquist G. Growth inhibitory effect of prostasomes on prostatic cancer cell lines in culture. Eur Urol 2000; 38: 468-74

28 Lwaleed BA, Bass PS, Francis JL,
Chisholm M. Functional and structural properties of urinary tissue factor. Nephrol Dialysis Transplantation 1999; 14: 588-96

29 Lwaleed BA, Bass PS, Francis JL, Chisholm M. Urinary tissue factor. A potential marker of disease. J Patho/ 1999; 188: 3-8

30 Abdulkadir SA, Carvalhal GF, Kalem Z et al. Tissue factor expression and angiogenesis in human prostate carcinoma. Hum Pathol 2000; 31: 403-5

31 Adamson AS, Luckert P, Pollard M, Snell ME, Amirkhosravi M, Francis JL. Procoagulant activity may be a marker of the malignant phenotype in experimental prostate cancer. Br J Cancer 1994; 69: 286-90
32 Ronquist G, Nilsson BO eds, Prostasomes. Proceedings from a Symposium at the Wenner-Gren Centre, Stockholm, June 2001. Wenner-Gren International Series, Vol. 81. Portland Press 2002

Correspondence: Alistair B. Stewart, Urology Research Office, E-Level, West wing, Mail Point 67, Southampton General Hospital, Tremona Road, Southampton, S016 6YD, UK. e-mail: alistairstewart@doctors.org.uk

Abbreviations: TF, tissue factor; HMW-SVP, high molecular weight seminal vesical proteins. 